\title{
THE DRYING PERFORMANCE AND POST-DRYING QUALITIES OF Eucalyptus saligna EXPOSED TO INTERMITTENT AND CONTINUOUS DRYING*
}

\author{
Karnita Yuniarti ${ }^{1 * *}$, Barbara Ozarska ${ }^{2 * *}$, Graham Brodie ${ }^{2}$, Gerry Harris ${ }^{2}$ and Gary Waugh ${ }^{2}$ \\ ${ }^{1}$ Center of Forest Products Research and Development Ministry of Environment and Forestry \\ Jl. Gunung Batu No. 5, West Java, Indonesia \\ ${ }^{2}$ University of Melbourne, Parkville, Victoria 3010, Australia
}

Received: 4 April 2020, Revised: 23 April 2020, Accepted: 25 April 2020

\begin{abstract}
THE DRYING PERFORMANCE AND POST-DRYING QUALITIES OF Eucalpptus saligna EXPOSED TO INTERMITTENT AND CONTINUOUS DRYING. Eucalyptus saligna tends to develop defects during its drying process, thus limiting its use as construction or furniture material. Intermittent drying, which applies non-heating phases between heating phases, has the potential to overcome this issue. This study evaluated the effects of 3 intermittent and one continuous schedule on the species' drying performance and post-drying qualities. The results showed that the boards from all intermittent schedules exhibit significantly slower drying rates (from $-9.4 \times 10^{-3} \% /$ hour to $-1.57 \times 10^{-2} \% /$ hour) than those from the continuous schedule (from $-5.12 \times 10^{-2} /$ hour to $-1.03 \times 10^{-2} \% /$ hour). All intermittent schedules tended to decrease the collapse depth in E. saligna boards (the average value range of the three schedules was $1.162-2.032 \mathrm{~mm}$ ) than the continuous schedule did (the average value was $5.12 \mathrm{~mm}$ ). Nevertheless, applying higher temperature than that used in the continuous schedule, during the heating phase of the intermittent schedule, potentially increased the moisture gradient, residual drying stress, end check length, internal check percentage, and spring depth.
\end{abstract}

Keywords: Eucalyptus saligna, drying performance, drying defects, intermittent drying, a continuous drying

PERFORMA DAN KUALITAS PENGERINGAN Eucalyptus saligna PADA PENGERINGAN INTERMITEN DAN KONTINYU. Eucalyptus saligna memiliki kecenderungan untuk mengalami cacat pengeringan, sehingga membatasi penggunaannya sebagai bahan konstruksi atau furnitur. Pengeringan intermiten, yang menerapkan fase pendinginan diantara fase pemanasan, berpotensi mengatasi masalab ini. Studi ini mengevaluasi pengaruh 3 skedul intermiten dan 1 skedul pengeringan kontinyu terhadap performa dan kualitas pengeringan jenis ini. Hasil studi menunjukean papan-

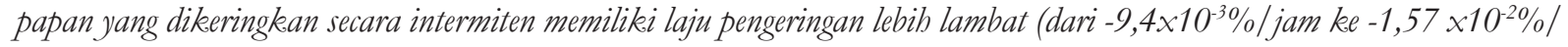
jam) dari yang dikeringkan secara kontinyu (dari -5,12 $\times 10^{-2 \%} / \mathrm{jam}$ ke $-1,03 \times 10^{-2 \%} / \mathrm{jam}$ ). Kedalaman kolaps yang terbentuk. pada papan-papan yang dikeringkan secara intermiten juga lebih rendah (1,162-2,032 mm) dari yang dikeringkan secara kontinyu $(5,12 \mathrm{~mm})$. Walaupun demikian, penerapan subu pengeringan yang lebih tinggi pada teknik intermiten dibandingkan dengan yang diterapkan pada teknik kontinyu berpotensi meningkatkan gradien kadar air, stress akbir pengeringan, panjang pecah ujung, persentase pecah dalam dan kedalaman pelengkungan kayu arah lebar sepanjang kayu.

Kata kunci: Eucalyptus saligna, performa pengeringan, cacat pengeringan, pengeringan intermiten, pengeringan kontinyu

\footnotetext{
* This study has been presented in the General Assembly and the $3^{\text {rd }}$ International Symposium of JSPS Alumni Association of Indonesia (ISJAAI-3) "The Role of JAAI to Promote Food, Water, Energy, Human, and Environmental Security", held on 31 October 2019 at Hotel Salak The Heritage, Bogor, West Java, Indonesia.

${ }^{* *}$ Corresponding author: karnita_yuniarti@yahoo.com, bo@unimelb.edu.au
} 


\section{INTRODUCTION}

Eucalyptus saligna or Sydney blue gum is a species that belongs to the Eucalyptus genus, a native to Australia, which is included in the Myrtaceae family (Elaieb et al., 2019). The species has now been grown outside Australia, including in China, Tunisia, Brazil, and Costa Rica (Arias-Aguilar et al., 2018; Beltrame et al., 2013; de Castro et al., 2015; Elaieb et al., 2019; Yang \& Liu, 2018). It is mainly cultivated for meeting the consumer demand on timber, pulp and essential oils which contain medicinal compounds (Elaieb et al., 2019; Luís, Nisgoski, \& Klitzke, 2018; Yang \& Liu, 2018).

A common issue often encountered during the utilization of any Eucalyptus species, including E. saligna, is the difficulties in their drying process. Due to its low permeability, slow drying, the development of high moisture gradients and collapse often observed in the majority of Eucalyptus species (Passarini \& Hernandez, 2016; Yuniarti, Ozarska, Brodie, Harris, \& Waugh, 2015). E. saligna even develops collapse at low temperature $\left(25^{\circ} \mathrm{C}\right)$ and posseses a lower collapse threshold temperature than $E$. regnans does (Yuniarti et al., 2015). Because it tends to develop drying defects, such as internal checking, collapse and shrinkage, post-drying recovery is recorded still low (Elaieb et al., 2019). This phenomenon could further limit its use as construction or furniture materials.

A review composed by Yang and Liu (2018) has proposed intermittent drying as an alternative technique can be opted to improve the drying quality of several Eucalyptus species. The method was firstly applied in enhancing the quality of several food crops, i.e. paddy, onion, soybean, etc. (Allaf etal., 2014; Golmohammadi, Foroughi-dahr, Rajabi-hamaneh, Shojamoradi, \& Hashemi, 2016; Park, Han, Kang, \& Yoo, 2017; Takougnadi, Boroze, \& Azouma, 2018). It works by introducing regular interruption during the drying process (Allaf et al., 2014; Yang \& Liu, 2018). Due to this periodic nonheating condition, more uniform distribution of moisture content and stress relaxation are expected to occur in the internal part of the wood (Yang \& Liu, 2018).

Up to now, studies on the application for intermittent drying for wood, in particular, to minimize the tendency possessed by E. saligna to develop drying defects have not received any attention. Therefore, this specific study aimed to examine the efficacy of various intermittent conditions in reducing the development of drying defects and also compare its effectiveness with the continuous schedules on both improving the drying performance and post-drying quality of E. saligna.

\section{MATERIAL AND METHOD}

\section{A. Study Site and Materials}

The study was conducted in the Burnley campus, the University of Melbourne, from January 2013 to September 2014. The primary material used for this experiment was E. saligna boards with original length was $860 \mathrm{~mm}$. Two biscuits, sizing $20 \mathrm{~mm}$ width, were taken at a distance of $50 \mathrm{~mm}$ from both ends of each board. These biscuits were used to determine the initial moisture content of each board. All boards were end sealed with silicone sealant and aluminium foils before the drying process. Each board was also marked following the pattern shown in Figure 1 below. The design was later used as guidance for cutting process of samples for measuring residual drying stress, observing internal checks and collapse. The experiment was carried out using three drying kilns in the carpentry workshop, Burnley campus, the University of Melbourne. Other equipment and tools used for this experiment were bandsaws, rip-saw, oven, scale, digital calliper, and a moisture meter.

\section{B. Methods}

The study applied three intermittent schedules and one continuous schedule as follow:

(i) Intermittent 1: heating phase for 13 hours at $38^{\circ} \mathrm{C}$ and relative humidity of $60 \%$, followed by non-heating at ambient condition for 11 hours (condensed as $\left.38^{\circ} \mathrm{C} / 60 \%, 13 \mathrm{H} / 11 \mathrm{NH}\right)$; 


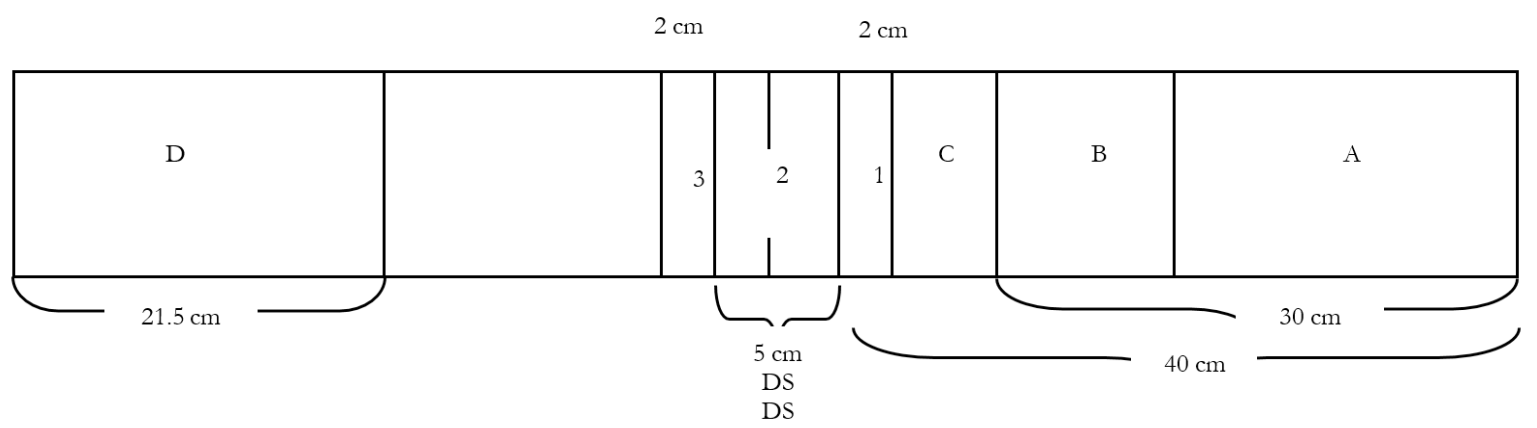

Remarks: 1 - Final moisture content biscuit; 2 - Drying stress sample (DS); 3 - Prong test sample B, C, D, DS - Internal check observation; A, D, DS - Collapse observation

Figure 1. Observation and cutting pattern for each dried board

(ii) Intermittent 2: heating period heating phase for 11 hours at $42^{\circ} \mathrm{C}$ and relative humidity of $60 \%$, followed by non-heating at ambient condition for 13 hours (condensed as $\left.42^{\circ} \mathrm{C} / 60 \%, 11 \mathrm{H} / 13 \mathrm{NH}\right)$;

(iii) Intermittent 3: heating phase for 9 hours at $45^{\circ} \mathrm{C}$ and relative humidity of $60 \%$, followed by non-heating at ambient condition for 15 hours (condensed as $\left.45^{\circ} \mathrm{C} / 60 \%, 9 \mathrm{H} / 15 \mathrm{NH}\right)$.

(iv) Continuous drying at $40^{\circ} \mathrm{C}$ and relative humidity of $60 \%$ (condensed as $40^{\circ} \mathrm{C} / 60 \%$ )

For all intermittent schedules, the heating phase was carried out during the day, and the non-heating phase was carried out at night. The fan speed was $300 \mathrm{rpm}$ (or equal to $10 \mathrm{GHz}$ ) for both phases. For continuous schedule, the air velocity applied was $12 \mathrm{Ghz}$ (fan speed of $350 \mathrm{rpm}$ ). Each schedule was carried out in different kilns.

Approximately three runs were applied for each schedule, except for intermittent one which only applied two runs. The number of boards used was 12 for each run, except for the 3 rd run of the continuous schedule (10 boards). The boards were stacked using the assistance of $20-\mathrm{mm}$ thick wooden stickers. Baffles were placed on the top and in front of the stack to avoid excessive airflow around those sections. The boards were weighed daily after each heating and non-heating phases, except in the weekend. After all, boards reached the final moisture content range of $10-15 \%$; the drying was stopped. A $20-\mathrm{mm}$ thick biscuit was cut from the middle of each board and further used to correct the moisture content values of the related board.

\section{Analysis}

The parameters observed from each drying schedule are:

(i) Drying performance parameters which were drying rate and time. The drying rate was determined by firstly transforming the moisture reduction data for each board into their natural logarithm values. Each data set from each board was then plotted in a graph with $\mathrm{x}$-axis represented time (hour), and $\mathrm{y}$-axis represented moisture content (\%). A linear equation was then applied to each figure. The drying rate for each board was the slope of the linear equation. Drying time was measured from the starting time of the drying process to the time when the average final moisture content of all the boards was approximately $10-15 \%$.

(ii) Post drying quality parameters followed those described in Australian standard-AS/ NZS 4787:2001 to assess the furniture and joinery grade products which were moisture gradient, residual drying stress, checking (surface check, end check, and internal check), distortion (bow, spring, twist, and cupping) and collapse. Except for distortion, 
the assessment and classification for the other parameters followed the procedures described in AS/NZS 4787:2001. The assessment and classification for distortion followed the methods described in AS/ NZS 2082: 2007.

One-way analysis of variance (ANOVA) was carried out to examine the significant effect of different intermittent and continuous drying schedules on the drying rate, moisture gradient and residual drying stress separately. Before that, a normality test was executed, i.e. Shapiro Wilk. If the normality test result meets the requirement, indicated by a probability value of more than 0.001, then the general parametric ANOVA test was executed. Otherwise, data transformation might be required, and a nonparametric ANOVA test was applied, i.e. Kruskal-Wallis. Following test, such as Tukey (for parametric procedure) and Mann-Whitney $\mathrm{U}$ (for non-parametric method), were used if the previous ANOVA tests showed significant results. The null hypothesis for each parameter was all drying schedules had no significant effect on the drying rate, moisture gradient and residual drying stress. Other post-drying quality parameters were tabulated, presented into graphs and analysed descriptively.

\section{RESULT AND DISCUSSION}

\section{A. Drying Rate and Time}

Table 1 shows the drying rate from all intermittent schedules ranged from $-9.4 \times 10^{-3}$ $\% /$ hour to $-1.57 \times 10^{-2} \%$ / hour, slower than that of the continuous drying which ranged from $-5.12 \times 10^{-2} \% /$ hour to $-1.03 \times 10^{-2} \% /$ hour. All intermittent schedules required a longer time (696-4403 hours) than the continuous drying

Table 1.Average drying rate (/hour) and time (hour) of intermittent and continuous drying of E. saligna

\begin{tabular}{|c|c|c|c|c|c|c|c|}
\hline \multirow[t]{2}{*}{ Schedule } & \multirow[t]{2}{*}{$\operatorname{Rep}_{* *}$} & \multicolumn{2}{|c|}{$\begin{array}{c}\text { Moisture content range } \\
(\%)\end{array}$} & \multicolumn{2}{|c|}{$\begin{array}{l}\text { Drying rate range } \\
\quad(\% \text { hour })^{*}\end{array}$} & \multicolumn{2}{|c|}{$\begin{array}{l}\text { Drying time } \\
\text { range (average, } \\
\text { hour) }\end{array}$} \\
\hline & & Green & Final & Min & Max & Min & Max \\
\hline \multirow{2}{*}{$\begin{array}{l}\text { Intermittent } 13 \text {-hour } \\
\text { heating at } 38^{\circ} \mathrm{C}, 60 \% \mathrm{RH} \\
\text { and } 11 \text {-hour non-heating } \\
\text { at ambient condition }\end{array}$} & 1 & $\begin{array}{l}79.87- \\
106.79\end{array}$ & $\begin{array}{l}11.52 \\
-12.39\end{array}$ & $-6.6 \times 10^{-3}$ & $-3.4 \times 10^{-3}$ & 3273 & 3753 \\
\hline & 2 & $\begin{array}{l}86.01- \\
137.24\end{array}$ & $\begin{array}{l}11.88- \\
12.65\end{array}$ & $-6.6 \times 10^{-3}$ & $-3.3 \times 10^{-3}$ & 3683 & 3951 \\
\hline \multirow{3}{*}{$\begin{array}{l}\text { Intermittent } 11 \text {-hour } \\
\text { heating at } 42^{\circ} \mathrm{C}, 60 \% \mathrm{RH} \\
\text { and } 13 \text {-hour non-heating } \\
\text { at ambient condition }\end{array}$} & 1 & $\begin{array}{l}80.34- \\
111.62\end{array}$ & $\begin{array}{r}11.20 \\
-13.67\end{array}$ & $-2.7 \times 10^{-2}$ & $-2.04 \times 10^{-2}$ & 971 & 1248 \\
\hline & 2 & $70.44-88.23$ & $\begin{array}{l}11.55- \\
11.97\end{array}$ & $-2.26 \times 10^{-2}$ & $-1.58 \times 10^{-2}$ & 1176 & 1632 \\
\hline & 3 & $\begin{array}{l}79.72- \\
148.99\end{array}$ & $\begin{array}{l}11.56- \\
13.01\end{array}$ & $-2.4 \times 10^{-3}$ & $-2.4 \times 10^{-3}$ & 4163 & 4403 \\
\hline \multirow{4}{*}{$\begin{array}{l}\text { Intermittent } 9 \text {-hour } \\
\text { heating at } 45^{\circ} \mathrm{C}, 60 \% \mathrm{RH} \\
\text { and } 15 \text {-hour non-heating } \\
\text { at ambient condition }\end{array}$} & 1 & $\begin{array}{l}80.55- \\
126.13\end{array}$ & $\begin{array}{l}11.79- \\
14.99\end{array}$ & $-2.48 \times 10^{-2}$ & $-1.57 \times 10^{-2}$ & 1281 & 1599 \\
\hline & 2 & $71.62-84.42$ & $\begin{array}{c}11.64- \\
11.99\end{array}$ & $-4.10 \times 10^{-2}$ & $-1.69 \times 10^{-2}$ & 696 & 1488 \\
\hline & 3 & $\begin{array}{l}83.46- \\
159.03\end{array}$ & $\begin{array}{l}10.68- \\
11.87\end{array}$ & $-9.4 \times 10^{-3}$ & $-4.5 \times 10^{-3}$ & \multicolumn{2}{|c|}{2823} \\
\hline & 1 & $\begin{array}{l}80.59- \\
113.87\end{array}$ & $\begin{array}{l}11.70- \\
11.99\end{array}$ & $-3.39 \times 10^{-2}$ & $-2.3 \times 10^{-2}$ & 780 & 1092 \\
\hline \multirow[t]{2}{*}{$\begin{array}{l}\text { Continuous process at } \\
40^{\circ} \mathrm{C}, 60 \% \mathrm{RH}\end{array}$} & 2 & $\begin{array}{l}85.81- \\
120.68\end{array}$ & $\begin{array}{l}11.48- \\
11.99\end{array}$ & $-5.12 \times 10^{-2}$ & $-2.11 \times 10^{-2}$ & 588 & 1092 \\
\hline & 3 & $\begin{array}{l}76.27- \\
132.39\end{array}$ & $\begin{array}{l}11.61- \\
12.29\end{array}$ & $-3.90 \times 10^{-2}$ & $-1.03 \times 10^{-2}$ & 876 & 1992 \\
\hline
\end{tabular}

Remarks : * indicates declining trend; **each replication consisted of 12 samples 


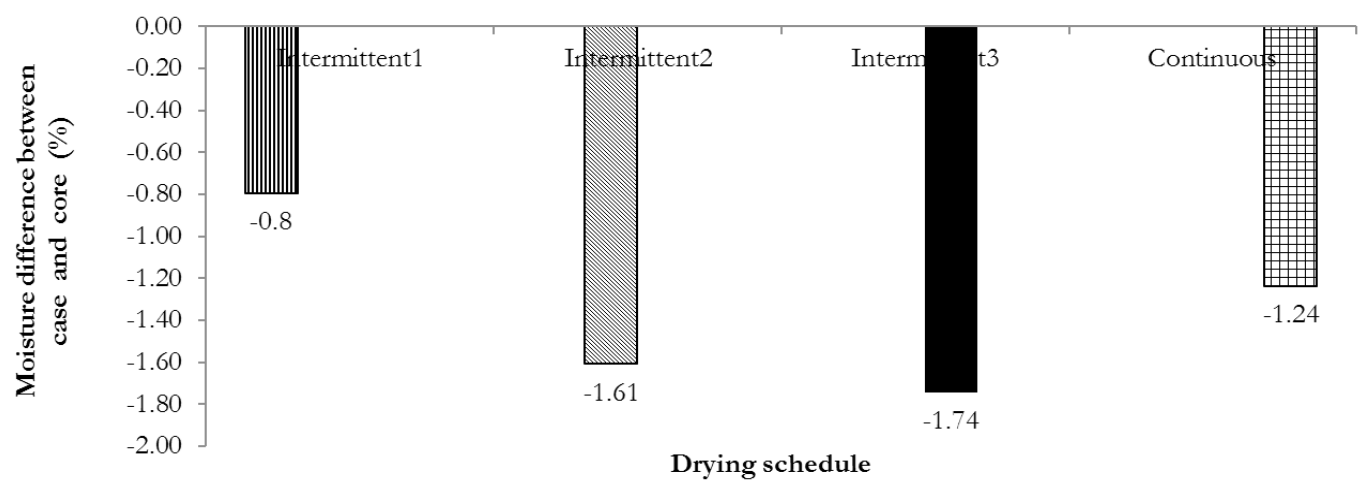

m Intermittent1 (13-hour heating at 38oC 60\% \& 11-hour non-heating)

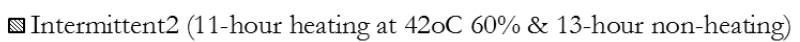

- Intermittent3 (9-hour heating at 45oC 60\% \& 15-hour non-heating)

$\boxplus$ Continuous drying

Figure 2. Average moisture gradient (between the case and core) in E. saligna exposed to the intermittent and continuous drying schedules

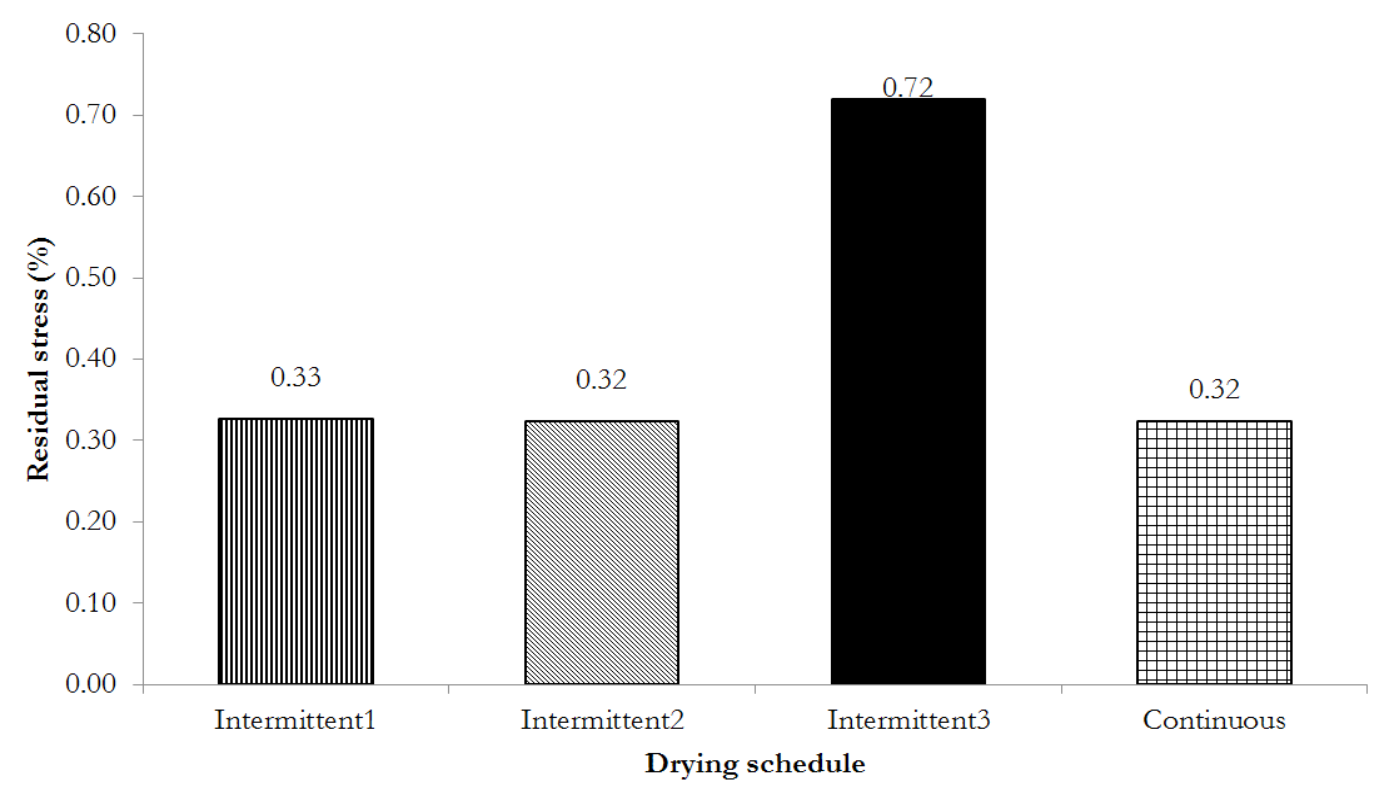

Figure 3. Average residual stress (\%) in E. saligna exposed to the intermittent and continuous drying schedules

did (588-1992 hours) to dry E. saligna to reach moisture content $12 \% \pm 3$.

Further ANOVA showed that the drying schedules significantly affected the drying rate. A subsequent test showed that the drying rate between the intermittent schedules and continuous schedules was significantly different, but not between the intermittent schedules 2 and 3 (Appendix 1). The significant difference between intermittent and continuous schedules was due to the uninterrupted heating condition in the continuous drying, which caused the wood to dry faster than those from the intermittent schedule.

\section{B. Moisture Gradient}

Figure 1 shows the boards from the intermittent schedule 3 had the highest 


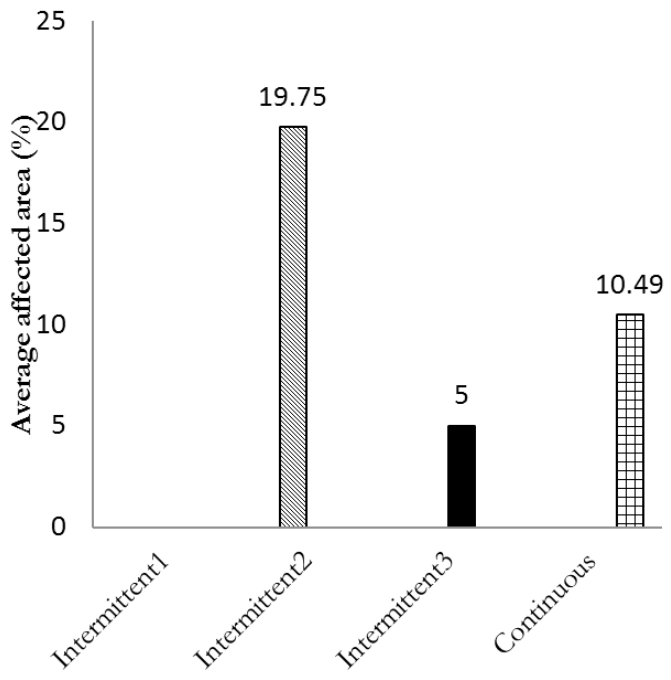

(a)

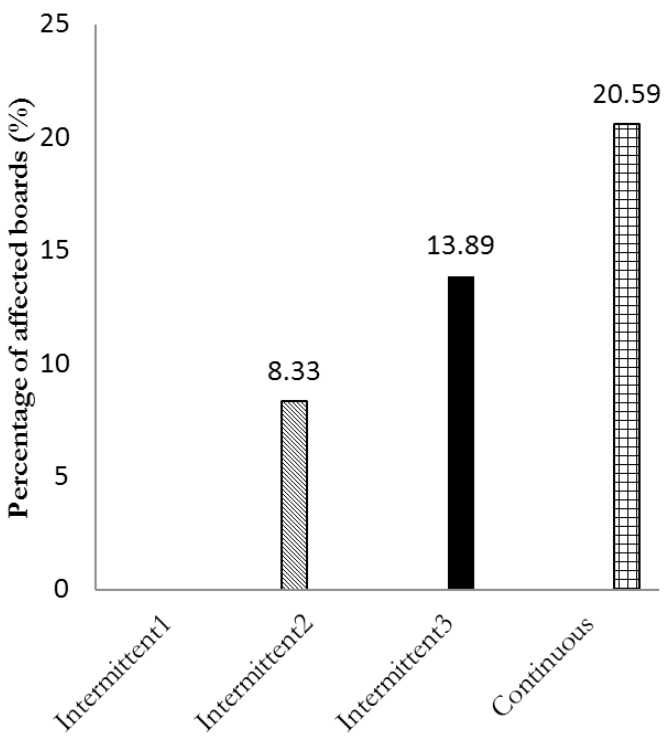

(b)

Figure 4 . The affected area by surface check (a) and the percentage of E. saligna boards with this defect (b) from the intermittent and continuous drying schedules

$(-1.74 \%)$, and schedule 1 had the lowest value $(-0.80 \%)$ of moisture gradient. The use of higher temperature during the practice of intermittent schedule 3 than that used for the intermittent schedule 1 possibly contributed to this result. Further ANOVA confirmed that different drying schedules significantly affected the moisture gradient values (Appendix 2).

\section{Residual Drying Stress}

Figure 3 shows the boards subjected to the intermittent schedule 3 developed the highest average residual drying stress $(0.72 \%)$. The result was unexpected and assumed to be due to the high temperature used for this schedule. On the other hand, the lowest residual drying stress, $0.32 \%$, was found for the boards exposed to the intermittent schedule 2. The boards from the continuous drying schedule also generated the same residual drying stress degree. This result implies that drying E. saligna with either continuous or intermittent schedule 2 will produce the same degree of residual drying stress. Further ANOVA confirmed that the degree of residual stress was significantly affected by the drying schedules applied (Appendix 3).

\section{Checking}

\section{Surface check}

Figure 4 shows the average affected area due to surface checks and the percentage of boards affected by this defect from the intermittent and continuous drying schedules. The surface checks were not found in the boards from the intermittent schedule 1. The highest affected area due to the surface check was observed in the boards from the intermittent schedule 2 $(19.75 \%)$.

Nevertheless, the highest percentage of boards affected by the surface check was from the continuous drying schedule (approximately $20.59 \%$ of the boards observed). This result was possibly due to the uninterrupted heating condition during the continuous drying. This continuous heating condition did not provide sufficient momentum for moisture equalization between the surface and the interior of the wood. The surface kept drying whilst the interior section of the wood was still wet, resulting in more surface checks.

The intermittent schedule 3, on the other hand, produced the lowest percentage of boards affected by surface check (13.89\%) 


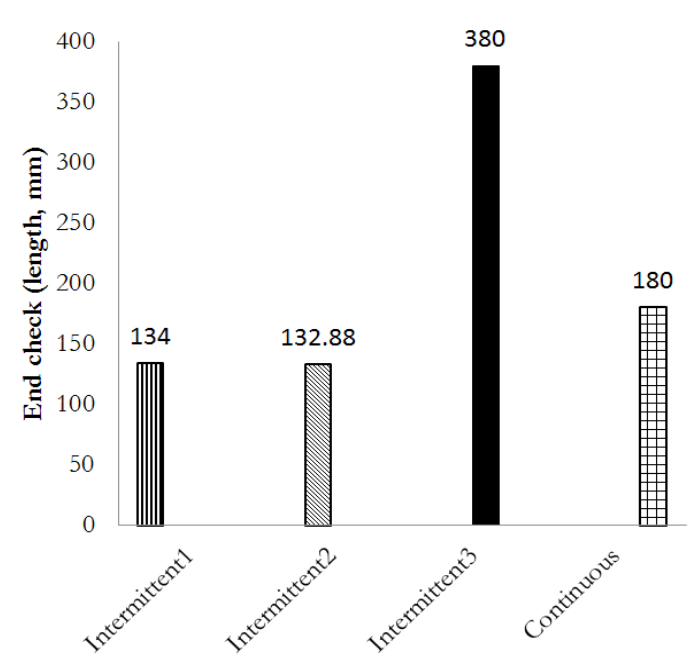

(a)

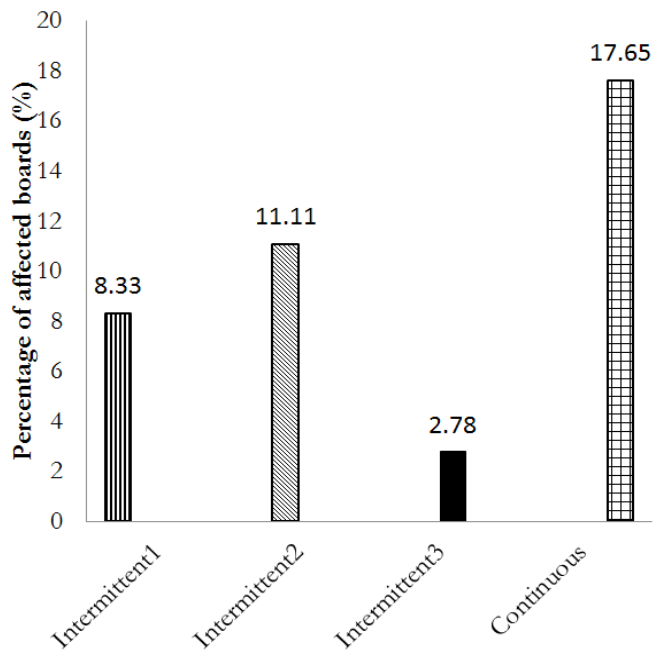

(b)

Figure 5. End check length (a) and the percentage of E. saligna boards with end checks (b) from the intermittent and continuous drying schedules

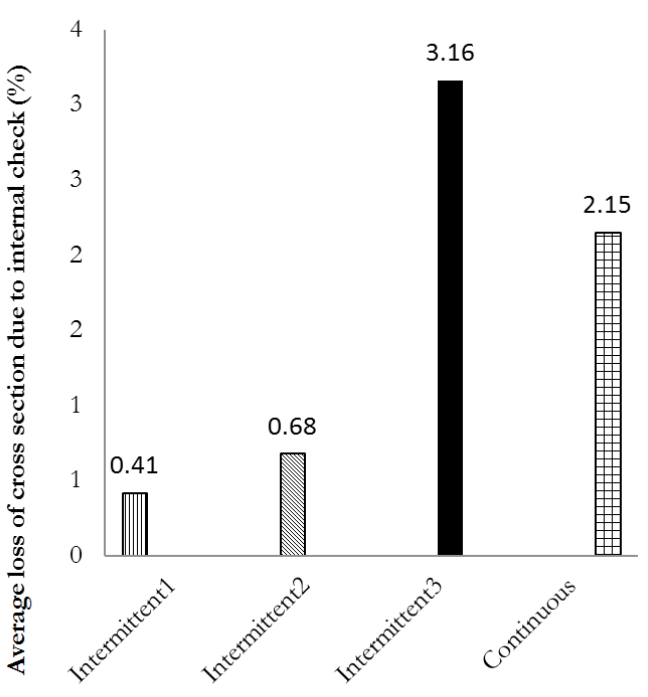

(a)

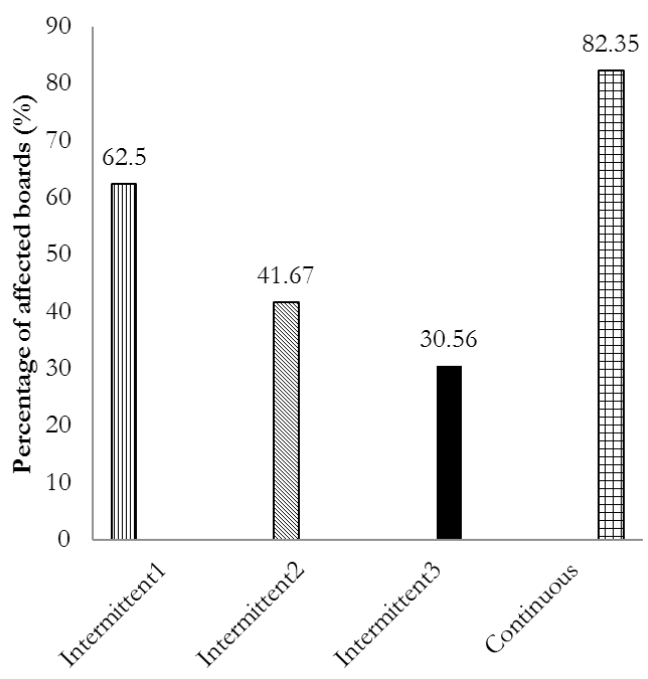

(b)

Figure 6. Internal check degree (\% affected area) (a) and the percentage of E. saligna boards with this defect (b) from the intermittent and continuous drying schedules

and the lowest affected area (5\%). This result was possibly due to the long non-heating period during the intermittent schedule 3, which provide recovery time for the boards to relieve surface checks. This result indicates that particular intermittent drying schedule is potential to reduce the tendency of E. saligna to develop surface checks during its drying process.

\section{End check}

Figure 5 shows the highest average length of end checks in the boards was from the intermittent schedule $3(380 \mathrm{~mm})$. The average lengths of end checks in the boards from the other intermittent schedules were lower than that from the continuous drying schedule. This result indicates that several intermittent drying schedules have the potential to reduce the 
tendency of E. saligna to develop end checks during its drying process.

Nevertheless, end checks only affected $2.78 \%$ of the boards used in the trial of intermittent schedule 3. The highest percentage of boards affected by end checks was from the continuous drying schedule. Approximately $17.65 \%$ of the boards subjected to the continuous trial were found with end checks.

\section{Internal check}

The study found that that the longitudinal direction of the internal checks commonly laid along the wood ray or perpendicular to the growth ring. Figure 6 further shows the percentage of boards affected by internal checks in the boards from all intermittent drying schedules was lower than that from the continuous drying schedule (82.35\%). This result indicates that the intermittent drying has the potential to reduce the tendency of E. saligna to develop internal checks during its drying process. Nevertheless, the highest average cross-section loss due to the presence of internal checks was found for the boards from the intermittent schedule $3(3.16 \%)$. Phonetip (2018) recommended using an imaging software to quantify the cross-section loss instead of the calliper method introduced in Australian New Zealand Standard AS/NZS 4787:2001. He argued that the imaging software technique captured the original shape of the internal check better than the calliper method. His study found that using imaging software technique resulted in a smaller figure than the calliper method did. However, it still has less effect on the grading classification of the wood according to the refereed standard.

Furthermore, review of Figures 4-6 shows that the internal checks were the dominant type of defect found for E. saligna regardless of the drying schedule used. The number of boards affected by other checks from all schedules was lower than those affected by internal checks. Of all the three check types, the internal check is possibly the most significant defect due to its concealed nature. The presence of internal checks is often only revealed after the drying process ends or during further manufacturing processing. Due to its presence, the industry is possibly not able to utilize the affected boards for high-quality products.

\section{E.Distortion}

Figure 7 shows the average value of cupping, bow, spring and twist developed in E. saligna boards from the intermittent and continuous drying schedules. Boards from the continuous

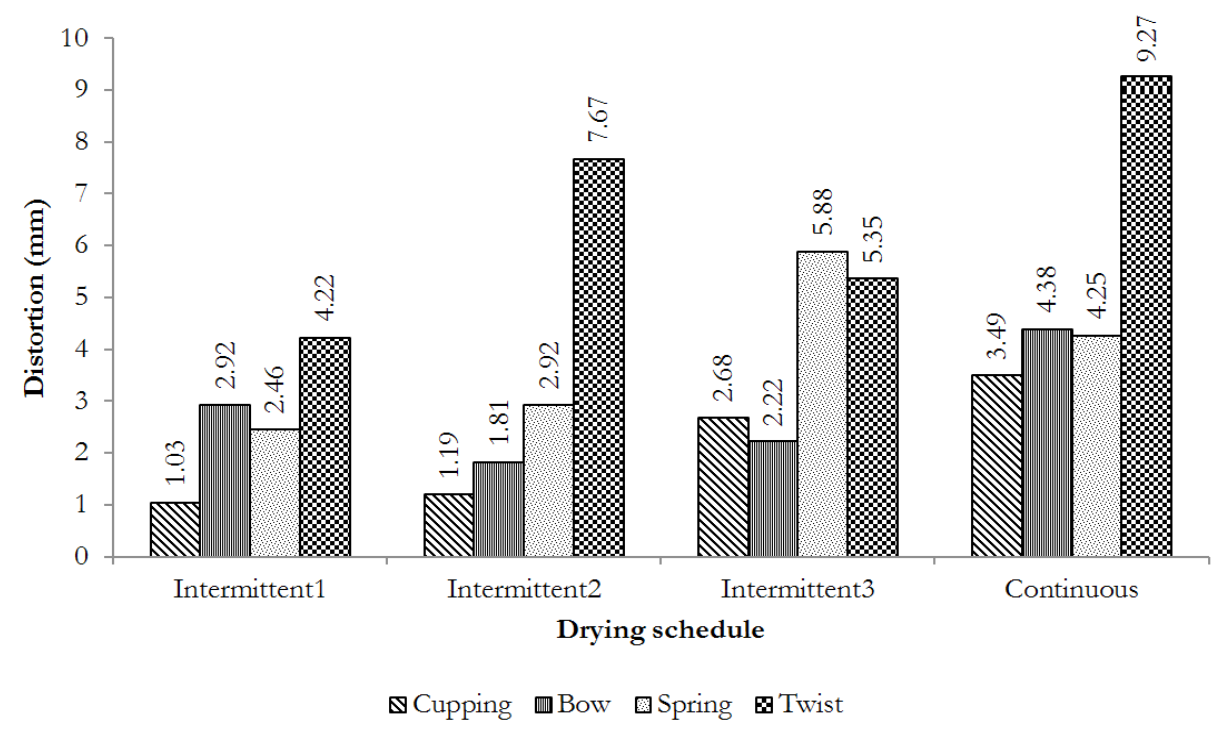

Figure 7. Cupping, bow, spring and twist in E. saligna boards from the intermittent and continuous drying schedules 


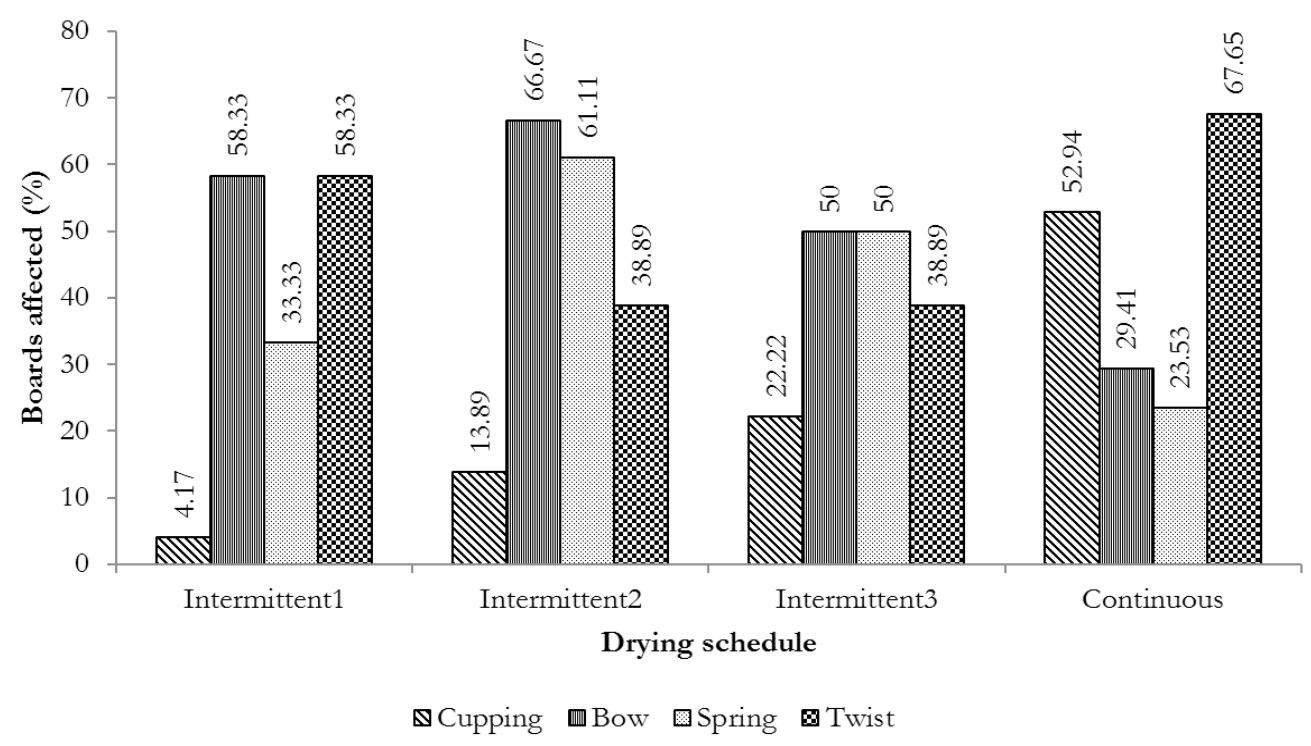

Figure 8. Percentage of boards affected by each distortion from the intermittent and continuous drying schedules

drying schedule had a higher average depth of twist $(9.27 \mathrm{~mm})$, bow $(4.38 \mathrm{~mm})$ and cupping $(3.49 \mathrm{~mm})$ than those from the intermittent drying schedules (Figure 7). This result was possibly due to interrupted heating condition in the intermittent drying schedule, which allowed moisture redistribution in the wood. The highest spring, on the other hand, was observed in the boards from the intermittent schedule 3 $(5.88 \mathrm{~mm})$ (Figure 7). The lowest spring depth was found for the boards from intermittent schedule1 (2.46 mm) (Figure 7).

Figure 8 shows the percentage of boards affected by each distortion type from intermittent and continuous drying schedules. The twist was not only the distortion type with the highest degree among other distortion for the boards from the continuous drying schedule $(9.27 \mathrm{~mm})$ (Figure 7) but also the most frequently found. The number of boards from the continuous schedule with a twist $(67.65 \%)$ was the highest among other schedules (Figure 8). The continuous schedule also caused the highest number of boards with cupping, among other schedules (53\%).

For intermittent schedule 1, twist and bow were the two most dominant distortion types and affected $58.83 \%$ of the boards from this intermittent schedule (Figure 8). Nevertheless, the twist was the distortion type with the highest degree among other defects for boards from the intermittent schedule $1(4.22 \mathrm{~mm})$ (Figure 7).

For the boards from the intermittent schedules 2, the bow was also the most frequent distortion found and affected 66.67\% of the boards used for this schedule (Figure 8). The percentage of boards with the bow from this schedule was the highest among other schedules. As well, the number of boards from this schedule with spring $(61.11 \%)$ was also the highest among other schedules (Figure 8). Nevertheless, the twist was still the type of distortion with the highest degree among other defects for the boards from the intermittent schedule 2 (7.67 mm) (Figure 7).

For the boards from the intermittent schedules 3, bow and spring were the two dominant distortion types found and affected $50 \%$ of the boards used for this schedule (Figure 8). Spring, on the other hand, was the distortion type with the highest degree among other defects for the boards from the intermittent schedule $3(5.88 \mathrm{~mm})$ (Figure 7).

The result obtained has shown that all distortion types developed to different degrees 


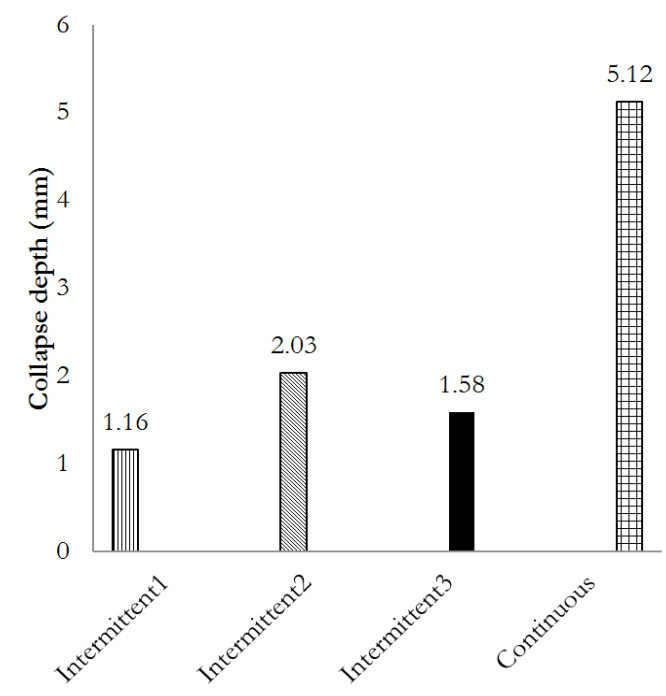

(a)

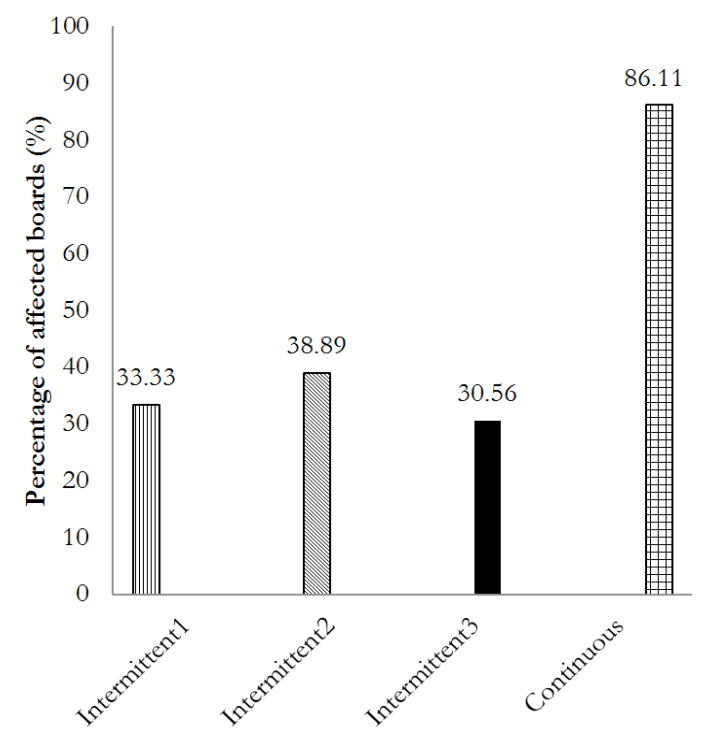

(b)

Figure 9. Average collapse depth in E. saligna boards and percentage of affected boards from the intermittent and continuous drying schedules

in E. saligna boards from the intermittent and continuous drying schedules. It is possible that when a particular distortion develops to a particular degree within board, the other distortion defects do not occur or develop at a different degree. Furthermore, the dominant distortion type developed can also indicate the possible wood reaction to the stress formed during the drying process.

\section{F. Collapse}

Figure 9 shows the average collapse depth in E. saligna boards and the percentage of affected boards from the intermittent and continuous drying schedules. The boards from all intermittent schedules developed a smaller degree of collapse (1.16-2.03 $\mathrm{mm}$ in depth) than those from the continuous schedule $(5.12 \mathrm{~mm})$. As well, the percentage of affected boards from the intermittent schedules (30.56-38.89\%) was smaller than that from the continuous schedule $(86.11 \%)$.

The low level of collapse in intermittentlydried boards, in comparison to those observed in the continuously-dried boards, is assumed to be due to the inclusion on non-heating phase, which allows redistribution of moisture content. This phenomenon could assist in improving the permeability of wood, thus inducing internal stress relaxation. According to Elaieb et al. (2019), increased permeability should allow the wood to minimize its tendency to develop collapse. Another intermittent drying experiment with Eucalyptus delegatensis as the object revealed that increasing relative humidity up to $80-90 \%$ during the non-heating phase was potential to reduce both the depth and percentage of boards affected by collapse (Phonetip, 2018).

On the other side, the high degree of collapse in the continuously-dried boards, in the context of the collapse depth and the percentage of affected boards, could be driven by non-stop heating from the beginning of the process. According to Couceiro, Vikberg, Hansson, and Morén (2016), rapid warming up phase during a drying process will lead to collapse and crack in the wood in the early stages. Yuniarti et al. (2015) observed that continuous heating, even at a temperature as low as $20-25^{\circ} \mathrm{C}$, still triggered some collapse to occur on E. saligna which was indicated by corrugated surfaces and internal checks. 


\section{CONCLUSION}

The study has shown that all intermittent schedules needed longer time (approximately 696-4403 hours) than the continuous drying did (approximately 588-1992 hours) to dry E. saligna to reach moisture content $12 \%+3$. The drying rate of all intermittent schedules applied (from $-9.4 \times 10^{-3} \%$ /hour to $-1.57 \times 10^{-2} \%$ /hour) was slower than that of the continuous drying (from $-5.12 \times 10^{-2} \% /$ hour to $-1.03 \times 10^{-2} \% /$ hour.). Further analysis of variance test showed that the drying schedules significantly affected the drying rate. The intermittently-dried boards generally possessed a lower degree of cupping, bow, twist, and collapse; and smaller percentage of boards affected by all checks types, cupping, twist and collapse than the continuously-dried boards did. Nevertheless, applying a higher heating-phase temperature in intermittent drying schedule (intermittent schedule 3) than that applied in the continuous schedule potentially increased the tendency of E. saligna to develop the steepest internal moisture gradient and average residual drying stress. It also possibly raised the percentage of crosssection loss due to the internal check presence, the length of the end check, and the depth of spring.

Further observation shows that internal check was the most frequent check developed in E. saligna boards from both intermittent and continuous drying schedules. Twist was the most frequent distortion occurred in the boards from the continuous schedule. Boards from intermittent schedule 1 also developed mostly twist and bow. The bow was also the dominant distortion in the boards from intermittent schedules 2 and 3. Besides, spring was also found to be the other dominant distortion for the boards from intermittent schedule 3. All intermittent schedules trialled for this experiment are suitable for E. saligna. However, if a moderate drying period and defects are the considerations, intermittent schedule 2 or 3 could be opted for the time being. To obtain faster drying period with minimum or no defects will require further intensive experiments.

\section{REFERENCES}

Allaf, K., Mounir, S., Negm, M., Allaf, T., Ferrasse, H., \& Mujumdar, A. (2014). Intermittent Drying. In A. Mujumdar (Ed.), Handbook of industrial drying (Vol. $4^{\text {th }}$, pp. 491-501). CRC Press. doi://10.1201/b17208-25.

Arias-Aguilar, D., Briceño-Elizondo, E., Calvo, M., Guevara-Bonilla, M., Valverde-Otárola, J., Esquivel-Segura, E. ., \& Arias-Ceciliano, K. (2018). Growth, carbon and nutrients dynamics in Eucalyptus saligna Sm. and Eucalyptus teriticornis Sm. short-rotation plantations in the highlands of Costa Rica. In Proceedings of Energy and Sustainability for Small Developing Economies (ES2DE) (pp. 1-8). doi: doi.org/10.1109/ES2DE.2018.8494323.

Beltrame, R., Mattos, B., Haselein, C., Santini, E., Gatto, D., \& de Cademartori, PHG Pedrazzi, C. (2013). Evaluation of longitudinal residual strain of Eucalyptus saligna Smith. wood. Scientia Forestalis, 41(97), 95-101. Retrieved from https://www.ipef.br/publicacoes/ scientia/nr97/cap10.pdf at 12 February 2019.

Couceiro, J., Vikberg, T., Hansson, L., \& Morén, T. (2016). In situ CT-scanning of checking and collapse behaviour of Eucalyptus nitens during drying. In Proceedings of the $59^{\text {th }}$ International Convention of Society of Wood Science and Technology (pp. 9-15). Curitiba, Brazil. Retrieved from https://www.diva-portal.org/ smash/get/diva2:1070722/FULLTEXT01. pdf

de Castro, V., Braz, R., Azambuja, R., Loiola, P., Iwakiri, S., \& Mato, J. (2015). Paineis cimentomadeira de Eucalyptus saligna com diferentes aditivos quimicos e metodos de formacao. Floresta, 45(2), 349-360. doi://10.5380/ rf.v45i2.35765.

Elaieb, M., Ayed, S., Ouellani, S., Khouja, M., Touhami, I., \& Candelier, K. (2019). Collapse and physical properties of native and presteamed Eucalyptus camaldulensis and Eucalyptus saligna wood from Tunisia. Journal of Tropical Forest Science, 31(2), 162-174. doi://10.26525/ jtfs2019.31.2.162174.

Golmohammadi, M., Foroughi-dahr, M., Rajabihamaneh, M., Shojamoradi, A., \& Hashemi, S. (2016). Study on drying kinetics of paddy rice: Intermittent drying. Iranian Journal of Chemistry and Chemical Engineering, 35(3), 105-117. 
Luís, R., Nisgoski, S., \& Klitzke, R. (2018). Effect of steaming on the colorimetric properties of Eucalyptus saligna wood. Floresta e Ambiente, 25(1). doi: //10.1590/2179-8087.101414.

Park, H., Han, W., Kang, H., \& Yoo, W. (2017). Drying characteristics of soybean (Glycine max) using continuous drying and intermittent drying. In Proceedings of the International Food Operations and Processing Simulation Workshop (pp. 8-15). Retrieved from http://www. msc-les.org/proceedings/foodops/2017/ FOODOPS2017_8.pdf at 9 February 2019.

Passarini, L., \& Hernandez, R. (2016). Effect of the desorption rate on the dimensional changes of Eucalyptus saligna wood. Wood Science \& Technology, 50, 941-951. doi://10.1007/ s00226-016-0839-8.

Phonetip, K. (2018). Investigating optimized drying methods for Eucalyptus delegatensis using a solar kiln. University of Melbourne. Retrieved from http://hdl.handle.net/11343/212529 at 1 October 2019.
Takougnadi, E., Boroze, T., \& Azouma, O. (2018). Development of an intermittent drying process of onion. Cogent Food \& Agriculture, 4(1). doi://10.1080/23311932.2017.1422225.

Yang, L., \& Liu, H. (2018). A review of Eucalyptus wood collapse and its control during drying. BioResources, 13(1), 2171-2181. Retrieved from https://ojs.cnr.ncsu.edu/index.php/BioRes/ article/view/BioRes_13_1_Yang_Review_ Eucalyptus_Wood_Collapse_Drying/5878 at 30 September 2019.

Yuniarti, K., Ozarska, B., Brodie, G., Harris, G., \& Waugh, G. (2015). Collapse development of Eucalyptus saligna under different drying temperatures. Journal of Tropical Forest Science, 27(4), 462-471. 


\title{
APPENDICES \\ Appendix 1. One-way ANOVA to assess the significant effect of applied drying schedule on drying rate
}

\author{
A. Shapiro-Wilk test for Normality* \\ Data variate: Slope \\ Test statistic W: 0.9286 \\ Probability: $<0.001$ \\ Remarks: * All transformation did not work
}

B. Kruskal-Wallis one-way analysis of variance

Variate: Slope

Group factor: Schedule

Value of $\mathrm{H}=55.11$

Adjusted for ties $=55.12$

\begin{tabular}{llr} 
Sample Size & \multicolumn{2}{c}{ Mean rank } \\
Group Continuous & 34 & 32.91 \\
Group Intermittent1 & 24 & 106.52 \\
Group Intermittent2 & 36 & 71.79 \\
Group Intermittent3 & 36 & 62.64
\end{tabular}

Degrees of freedom $=3$ Chi-square probability $<0.001$

C. Subsequent test: Mann-Whitney U (Wilcoxon rank-sum) test

(i) Variates: Intermittent1, Intermittent2.

Value of U: 263.5 (first sample has higher rank sum).

Exact probability (adjusted for ties): 0.010 (under null hypothesis that Intermittent1 is equal to Intermittent2). Sample sizes: 24, 36.

(ii) Variates: Intermittent1, Intermittent3.

Value of U: 24.0 (first sample has higher rank sum).

Exact probability $<0.001$ (under null hypothesis that Intermittent1 is equal to Intermittent3).

Sample sizes: 24,36 .

(iii) Variates: Intermittent1, Continuous.

Value of U: 0.0 (first sample has higher rank sum).

Exact probability $<0.001$ (under null hypothesis that Intermittent1 is equal to Continuous).

Sample sizes: 24,34 .

(iv) Variates: Intermittent2, Continuous

Value of U: 255.0 (first sample has higher rank sum).

Exact probability (adjusted for ties) $<0.001$ (under null hypothesis that Intermittent 2 is equal to Continuous). Sample sizes: 36, 34 .

(v) Variates: Intermittent3, Continuous.

Value of U: 269.0 (first sample has higher rank sum).

Exact probability (adjusted for ties) $<0.001$ (under null hypothesis that Intermittent 3 is equal to Continuous). Sample sizes: 36,34 .

(vi) Variates: Intermittent3, Intermittent2.

Value of U: 610.0 (second sample has higher rank sum).

Exact probability (adjusted for ties): 0.673(under null hypothesis that Intermittent3 is equal to Intermittent2).

Sample sizes: 36, 36. 


\section{Appendix 2. Statistical analysis for the difference in moisture gradient values between three intermittent and one continuous schedules}

A Normality Test: Shapiro-Wilk test*

Data variate: Difference

Test statistic W: 0.7762

Probability: $<0.001$

Remarks: * All transformation did not work.

B. Main test: Kruskal-Wallis one-way analysis of variance*

Variate: Gradient

Group factor: Schedule

Value of $\mathrm{H}=20.78$ Adjusted for ties $=20.78$

$\begin{array}{lll}\text { Sample** } & \text { Size } & \text { Mean rank } \\ \text { Group Int1 } & 24 & 93.27 \\ \text { Group Int2 } & 36 & 59.04 \\ \text { Group Int3 } & 36 & 49.76 \\ \text { Group Cont } & 33 & 67.56\end{array}$

Degrees of freedom $=3$ Chi-square probability $<0.001$

Remarks: * This non-parametric ANOVA was opted after normality test showed the data was not normally distributed and no transformation attempts were successful to improve it.

C. Subsequent test : Mann-Whitney U (Wilcoxon rank-sum) test

(i) Variates: Intermittent1, Intermittent 2.

Value of U: 234.5 (first sample has higher rank sum).

Exact probability (adjusted for ties): 0.002 (under null hypothesis that Sched1 is equal to Sched2). Sample sizes: 24,36 .

(ii) Variates: Intermittent 1, Intermittent 3.

Value of U: 150.0 (first sample has higher rank sum).

Exact probability (adjusted for ties) $<0.001$ (under null hypothesis that Sched1 is equal to Sched3). Sample sizes: 24,36 .

(iii) Variates: Intermittent 1, Continuous.

Value of U: 197.0 (first sample has higher rank sum).

Exact probability (adjusted for ties): 0.002 (under null hypothesis that Sched1 is equal to Sched4). Sample sizes: 24,33 .

(iv) Variates: Intermittent 2, Intermittent 3.

Value of U: 577.0 (first sample has higher rank sum).

Exact probability (adjusted for ties): 0.428 (under null hypothesis that Sched2 is equal to Sched3). Sample sizes: 36,36 .

(v) Variates: Intermittent 2, Continuous.

Value of U: 473.0 (second sample has higher rank sum).

Exact probability (adjusted for ties): 0.208 (under null hypothesis that Sched2 is equal to Continuous).

Sample sizes: 36, 33.

(vi) Variates: Intermittent 3, Continuous.

Value of U: 365.5 (second sample has higher rank sum).

Exact probability (adjusted for ties): 0.009 (under null hypothesis that Sched3 is equal to Continuous).

Sample sizes: 36, 33. 


\section{Appendix 3. Statistical analysis for differences in drying residual stress (standard-slicing test) between continuous and three intermittent schedules}

A Normality test : Shapiro-Wilk test*

Data variate: Stress

Test statistic W: 0.8643

Probability: $<0.001$

Transformation

Data variate: StressSQRT

Test statistic W: 0.9839

Probability: 0.161

B. Main test : 1-Way analysis of variance of an unbalanced design

Variate: Stress SQRT (the stress values were transformed into square root forms to obtain normal distribution)

Source of variation d.f

Schedule

Residual

Total

120 s.s. $\quad$ m.s.

2.16014

5.77500

7.93514

C. Subsequent test: Tukey test $95 \%$ confidence intervals

$\begin{array}{lllll} & \text { Difference } & \text { Lower } 95 \% & \text { Upper } 95 \% & \text { Significant } \\ \begin{array}{l}\text { Comparison* } \\ 4 \text { vs } 2\end{array} & -0.0010 & -0.1464 & 0.1444 & \text { no } \\ 4 \text { vs } 1 & -0.0198 & -0.1815 & 0.1418 & \text { no } \\ 4 \text { vs } 3 & -0.3025 & -0.4489 & -0.1561 & \text { yes } \\ 2 \text { vs } 1 & -0.0188 & -0.1742 & 0.1366 & \text { no } \\ 2 \text { vs } 3 & -0.3015 & -0.4409 & -0.1620 & \text { yes } \\ 1 \text { vs } 3 & -0.2826 & -0.4390 & -0.1263 & \text { yes }\end{array}$

Remarks:

* Group 1 = Intermittent at 380C 60\% RH, 13-hour heating, 11-hour non-heating Group 2 = Intermittent at 42 oC 60\% RH, 11-bour heating, 13-hour non-heating Group $3=$ Intermittent at $45 \circ \mathrm{C} 60 \% \mathrm{RH}$, 9-hour heating, 15-hour non-heating Group $4=$ Continuous at 40 oC $60 \% \mathrm{RH}$ 